\title{
Divergent Roles for TRAIL in Lung Diseases
}

\author{
Adam T. Braithwaite*, Helen M. Marriott and Allan Lawrie \\ Department of Infection, Immunity and Cardiovascular Disease, University of Sheffield, Medical School, Sheffield, \\ United Kingdom
}

The tumour necrosis factor-related apoptosis-inducing ligand (TRAIL) is a widely expressed cytokine that can bind five different receptors. TRAIL has been of particular interest for its proposed ability to selectively induce apoptosis in tumour cells. However, it has also been found to regulate a wide variety of non-canonical cellular effects including survival, migration and proliferation via kinase signalling pathways. Lung diseases represent a wide range of conditions affecting multiple tissues. TRAlL has been implicated in several biological processes underlying lung diseases, including angiogenesis, inflammation, and immune regulation. For example, TRAIL is detrimental in pulmonary arterial hypertension - it is upregulated in patient serum and lungs, and drives the underlying proliferative pulmonary vascular remodelling in rodent models.

OPEN ACCESS

Edited by:

Kian Fan Chung,

Imperial College London,

United Kingdom

Reviewed by:

Eleni Papakonstantinou,

Aristotle University of Thessaloniki,

Greece

Megan Noelle Ballinger,

The Ohio State University,

United States

*Correspondence:

Adam T. Braithwaite

a.braithwaite@sheffield.ac.uk

Specialty section:

This article was submitted to

Pulmonary Medicine,

a section of the journal

Frontiers in Medicine

Received: 28 February 2018

Accepted: 10 July 2018

Published: 27 July 2018

Citation:

Braithwaite AT, Marriott HM and Lawrie A (2018) Divergent Roles for

TRAIL in Lung Diseases.

Front. Med. 5:212.

doi: 10.3389/fmed.2018.00212
However, TRAIL protects against pulmonary fibrosis in mice models-by inducing apoptosis of neutrophils - and reduced serum TRAIL is found in patients. Conversely, in the airways TRAIL positively regulates inflammation and immune response. In COPD patients and asthmatic patients challenged with antigen, TRAIL and its death receptors are upregulated in serum and airways. Furthermore, TRAIL-deleted mouse models have reduced airway inflammation and remodelling. In the context of respiratory infections, TRAIL assists in immune response, e.g., via T-cell toxicity in influenza infection, and neutrophil killing in S. pneumoniae infection. In this mini-review, we examine the functions of TRAIL and highlight the diverse roles TRAIL has in diseases affecting the lung. Disentangling the facets of TRAIL signalling in lung diseases could help in understanding their pathogenic processes and targeting novel treatments.

Keywords: TRAIL, TNF-related apoptosis-inducing ligand, pulmonary arterial hypertension, immune regulation, pulmonary vascular disease, pulmonary fibrosis, respiratory tract infections, chronic obstructive pulmonary diseases

\section{INTRODUCTION}

The tumour necrosis factor-related apoptosis-inducing ligand (TRAIL), also known as Apo2 ligand is an apoptosis-inducing cytokine that is expressed in most cell types. As its name suggests, TRAIL was primarily of particular interest for its ability to selectively induce apoptosis in tumour cells in vitro and in vivo, while apparently exhibiting minimal off-target effects (1-3). TRAIL-deficient mice are also more susceptible to tumour formation and metastasis (4), suggesting TRAIL has a protective role in cancer suppression. Consequently TRAIL signalling has been targeted for use in several anticancer therapies (5), however several types of cancer cells are resistant to TRAILinduced apoptosis. In these cells, TRAIL can activate pro-inflammatory signalling pathways $(6,7)$, 
proliferation (8-10) and metastasis (11). The purpose of this mini-review is to discuss how the known function of TRAIL has evolved beyond apoptosis to these alternative effects and highlight the different roles TRAIL has in diseases affecting the lung (Figure 1), where TRAIL is widely expressed $(12,13)$. The better understanding of the diverse roles for TRAIL in lung disease could lead to the development of more effective, and novel treatments.

\section{TRAIL MOLECULAR SIGNALLING}

TRAIL, a type II transmembrane protein, is a member of the death receptor ligand family; a subclass of the tumour necrosis factor family (14) and is widely expressed in a variety of human tissues, most predominantly in lung, spleen and prostate (14). TRAIL is proteolytically-cleaved and its extracellular domain can bind five TRAIL receptors: membrane-bound death receptors DR4 (TRAIL-R1) and DR5 (TRAIL-R2), membrane-bound decoy receptors DcR1 (TRAIL-R3), and DcR2 (TRAIL-R4) and the soluble decoy osteoprotegerin (OPG) (15-21) [TRAIL is conserved in mice-they have two decoy receptors and a single TRAIL death receptor, mDR5, which is more similar to DR5 than DR4 (22)].

TRAIL is composed of 281 amino acids and forms a homotrimeric structure upon binding three receptor molecules (23). The death receptors DR4 and DR5 are type I transmembrane proteins containing a cytoplasmic death domain. In the canonical TRAIL apoptosis signalling pathway (Figure 2A), binding of death receptors by TRAIL leads to recruitment of Fas-associated protein with death domain (FADD), formation of a complex known as deathinducing signalling complex (DISC), activation of caspase- 8 and subsequently downstream caspase-3 dependent apoptosis of the cell [Figure 1; (24-26)]. Unlike the TRAIL death receptors, the decoy receptor DcR1 has no death domain $(15,18)$ and DcR2 has a truncated, non-functional death domain $(15,17,27)$. These decoy receptors, and additionally binding with lower affinity, the soluble OPG, are suggested to suppress apoptotic signalling by competitively binding TRAIL $(28,29)$.

Conversely, TRAIL can also stimulate pathways promoting cell survival, proliferation and migration via activation of kinase signalling pathways (Figure 2B) (30). This non-canonical signalling may depend on the formation of a secondary signalling complex after initial DISC assembly (31), recruiting other factors including FADD, Caspase 8, RIPK1, TNF receptorassociated factor 2 (TRAF2) and inhibitor of NF- $\kappa$ B kinase subunit gamma (IKK- $\gamma)$. Activation of non-canonical TRAIL signalling pathways may also be regulated by expression of DcR1, as antibody neutralisation of this decoy receptor can inhibit TRAIL-induced cell proliferation (30). Downstream noncanonical signalling by TRAIL has been shown to be effected

Abbreviations: COPD, Chronic obstructive pulmonary disease; DcR1/2, Decoy receptor 1/2; DISC, Death-inducing signalling complex; DR4/5, Death receptor 4/5; EC, Endothelial cell; PAH, Pulmonary arterial hypertension; PF, Pulmonary fibrosis; SMC, Smooth muscle cell; SSc, Systemic sclerosis. by activation of kinase signalling e.g., NF-кB, p38, c-Jun Nterminal kinase (JNK), phosphatidylinositide 3-kinases (PI3K), Akt, and extracellular signal-regulated kinases (ERK); leading to activation of gene transcription (32). By activating NF- $\kappa$, TRAIL can also modulate levels of FADD-like interleukin-1 $\beta$-converting enzyme)-inhibitory protein [c-FLIP; (33)], a negative regulator of caspase-mediated apoptosis-a further mechanism by which a cell may deviate from pro-apoptotic to pro-survival signalling in response to TRAIL.

\section{PULMONARY ARTERIAL HYPERTENSION}

TRAIL has been implicated in the pathobiology of pulmonary arterial hypertension $(30,34)$. This is indicated by elevated levels of soluble TRAIL found in the serum of PAH patients, and increased abundance of serum TRAIL, which is associated with worsened clinical severity (35). The pulmonary vasculature is complex, and many aberrant processes can lead to disease. $\mathrm{PAH}$ is a multifactorial disorder characterised by remodelling of the pulmonary arteries and a progressive increase in pulmonary vascular resistance, leading to raised afterload on the right ventricle and ultimately right heart failure (36). The most frequent alterations are sustained pulmonary vasoconstriction and remodelling of the pulmonary arteries and arterioles. The arterial remodelling is characterised by medial hypertrophy, intimal fibrosis and often the development of thrombotic or plexiform lesions (37). Together, these processes cause the occlusion of small pulmonary arteries. Combined with the muscularisation and progressive obliteration of distal vessels, the subsequent loss of cross-sectional area generates increased right ventricular afterload. At the cellular level, the neoplastic pathologies of $\mathrm{PAH}$ are thought to be driven by excessive proliferation of apoptosis-resistant endothelial cells (ECs), together with proliferation and migration of medial smooth muscle cells (SMCs) and fibroblasts.

TRAIL immunoreactivity has been shown in pulmonary vascular lesions from idiopathic PAH patients (13) and increased TRAIL mRNA expression is detected in the lungs of rodent models of PAH $(35,38)$. Furthermore, TRAIL has been demonstrated-by knockout and by inactivation-as necessary for the development of PAH in multiple pre-clinical models of $\mathrm{PAH}$ (30). Reversal of established PAH in rodent models was also demonstrated by administration of an anti-TRAIL antibody (30). TRAIL knockout also had a similar protective effect in a Sugen5416 and hypoxia mouse model of PAH (34). Increased TRAIL, DR4 and DcR1 mRNA levels have been detected in explanted pulmonary artery SMCs from idiopathic PAH patients, compared to healthy control cells (30). Additionally, TRAIL depletion or blockade in rodent models of $\mathrm{PAH}$ is associated with reduced pulmonary arterial remodelling with fewer proliferating pulmonary artery SMCs $(30,34)$. This evidence indicates that TRAIL is a key promoter of the pulmonary arterial SMC proliferation associated with the pathogenic vascular remodelling in PAH. Recombinant TRAIL was also shown to induce proliferation and migration of idiopathic $\mathrm{PAH}$ patient pulmonary artery SMCs in vitro, via phosphorylation of ERK1/2 (30). The 


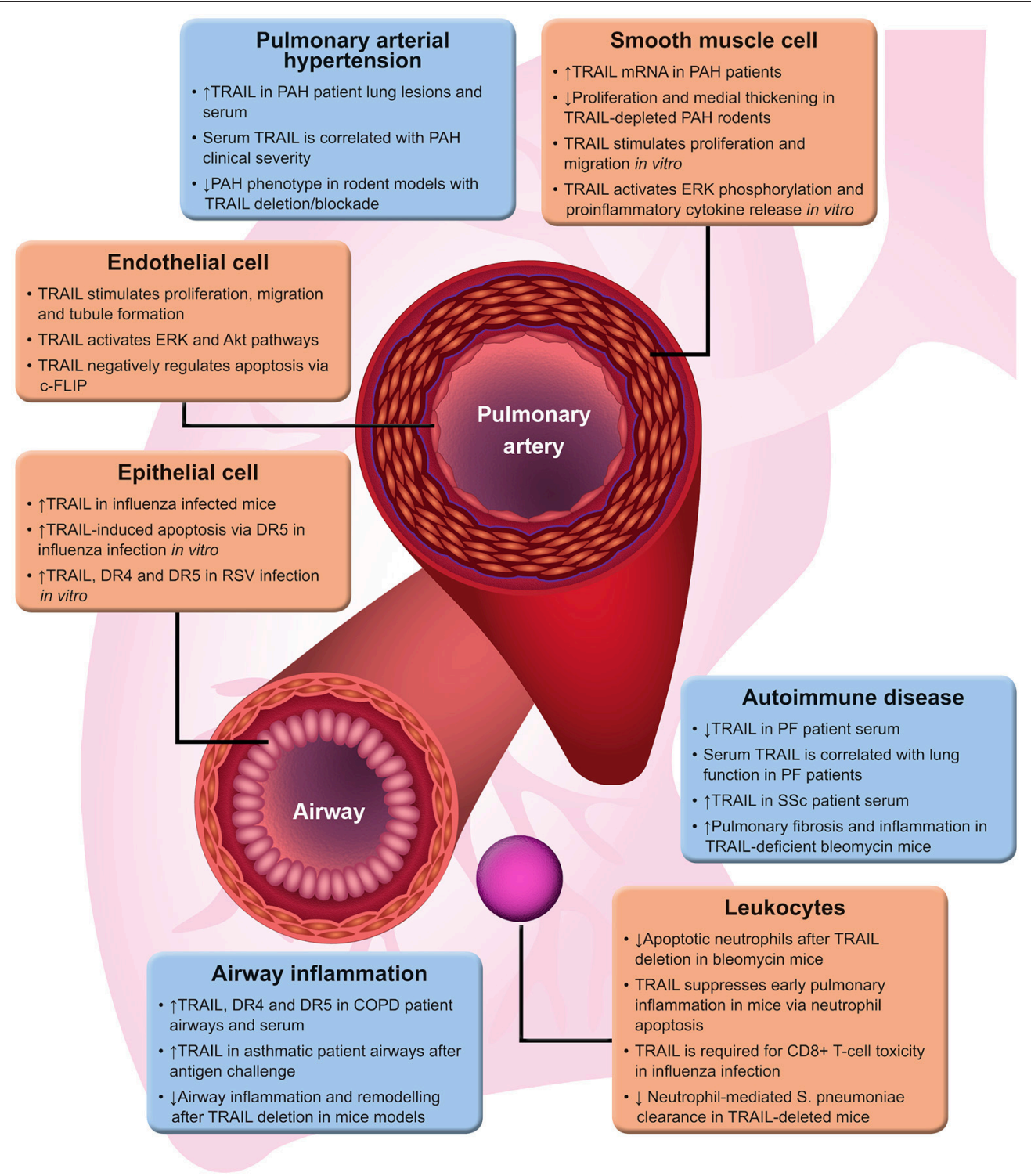

FIGURE 1 | TRAIL functions in lung disease. A brief summary of evidence for the varied roles of TRAIL in different lung diseases. $\uparrow$ and $\downarrow$ represent up- and down-regulation, respectively. Akt, protein kinase B; COPD, chronic obstructive pulmonary disease; DR4/5, TRAIL death receptor 4/5; ERK, extracellular signal-regulated kinase; PAH, pulmonary arterial hypertension; PF, pulmonary fibrosis; RSV, respiratory syncytial virus; SSc, systemic sclerosis; TRAIL, tumour necrosis factor-related apoptosis-inducing ligand.

pro-proliferative effect of TRAIL was reversed by the addition of DcR1 neutralising antibody, suggesting this decoy receptor is essential to non-canonical TRAIL signalling in pulmonary artery SMCs. Other studies have similarly demonstrated that TRAIL can stimulate proliferation and migration of vascular SMCs via non-canonical kinase signalling cascades $(39,40)$. Additionally, following activation of NF- $\mathrm{KB}$, TRAIL has been shown to stimulate production and release of pro-inflammatory cytokines in vascular SMCs (41).

EC dysfunction is another key aspect of the angioproliferative state of pulmonary arteries in PAH. Several studies have demonstrated that TRAIL can stimulate angiogenic processes in vascular ECs in vitro, including proliferation $(33,42,43)$, migration $(33,43,44)$ and tubule formation (43). Similarly to non-canonical TRAIL signalling in SMCs, its angioproliferative effect in ECs has been linked to activation of Akt and ERK pathways (42), as well as upregulation of DcR2 (45). Conversely, TRAIL has also been demonstrated to have apoptotic $(12,46)$ and anti-angiogenic (47) effects on vascular ECs. The reason for this disparity is unclear, although each of these studies used a relatively high concentration of recombinant TRAIL $(100 \mathrm{ng} / \mathrm{ml})$, suggesting the pro-angiogenic signalling in endothelium may preferentially occur at lower TRAIL concentrations. In Cantarella et al. (33), high levels of TRAIL were shown to induce caspase 


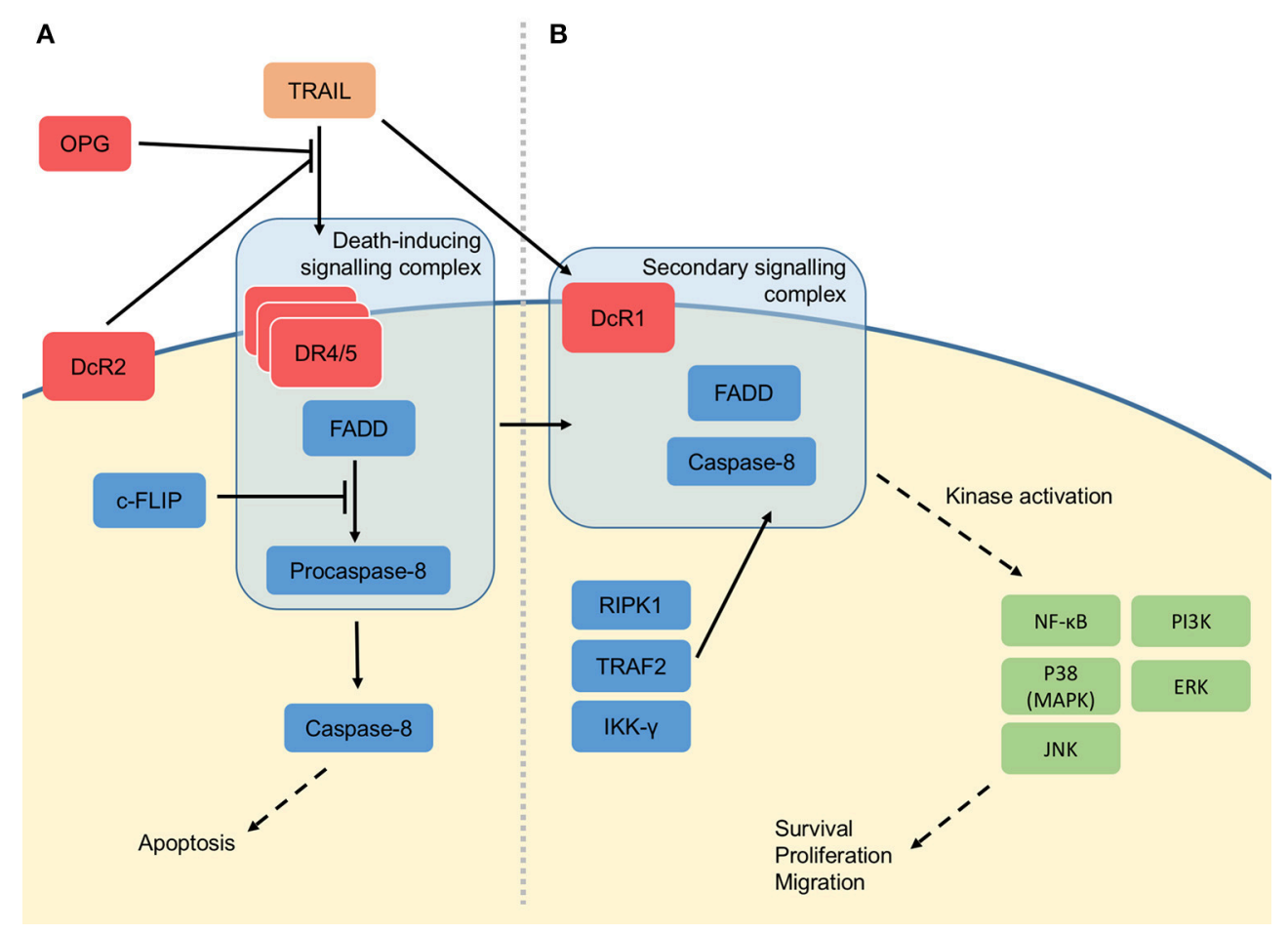

FIGURE 2 | Molecular signalling of TRAIL. (A) Three proteolytically-cleaved tumour necrosis factor-related apoptosis-inducing ligand (TRAIL) proteins form a homotrimeric structure when binding death receptor 4 (DR4) or death receptor 5 (DR5) at the cell membrane. These are joined by Fas-associated death domain (FADD) and procaspase-8 to form the so-called death-inducing signalling complex (DISC). The DISC causes activation of the caspase cascade, leading to apoptosis of the cell. TRAIL may also bind the membrane decoy receptors (DcR1/2) or soluble osteoprotegerin (OPG), which do not contain a death domain, thus preventing TRAIL-induced apoptosis. Apoptosis can also be suppressed by (FADD-like interleukin-1 $\beta$-converting enzyme)-inhibitory protein (c-FLIP), which inhibits the function of the DISC. (B) In the non-canonical signalling pathway, the receptor and ligand are thought to be lost, leaving FADD and caspase-8 to be joined by receptor-interacting serine/threonine-protein kinase 1 (RIPK1), TNF receptor-associated factor 2 (TRAF2) and inhibitor of NF-кB kinase subunit gamma (IKK- $\gamma$ ). This secondary signalling complex initiates protein kinase signalling pathways, leading to activation of kinases including nuclear factor kappa-light-chain-enhancer of activated B cells (NF-кB), p38 (mitogen-activated protein kinase; MAPK), c-Jun N-terminal kinase (JNK), phosphatidylinositide 3-kinases (PI3K) and extracellular signal-regulated kinase (ERK). The effects of these kinases include survival, proliferation and migration.

8-mediated apoptosis of ECs, whereas low levels of TRAIL were pro-angiogenic. Interestingly, these dose-dependent opposing effects of TRAIL in ECs were linked to modulation of levels of c-FLIP, a procaspase- 8 homolog and negative regulator of apoptosis (33).

\section{AUTOIMMUNE DISEASE}

TRAIL is now known to have crucial functions in regulation of inflammation and immune response. These systems are significant in the pathogenesis of many forms of lung disease, including autoimmune disorders and respiratory infection in addition to pulmonary vascular disease (Figure 2). A role for TRAIL in regulating inflammation via apoptosis was highlighted in a knockout of the mouse TRAIL death receptor, as in addition to tumour formation, the mice were prone to chronic inflammation (48). Additionally, TRAIL has been demonstrated to suppress the early inflammatory response via apoptosis of neutrophils (49).

$\mathrm{PAH}$ is an associated complication in autoimmune disease, e.g., 7-12\% of patients with systemic sclerosis (SSc) develop
PAH (50, 51). SSc is a heterogeneous autoimmune disorder, characterised by tissue fibrosis and vascular injury. Pulmonary fibrosis (PF) is a condition often found in interstitial lung disease and autoimmune disorders of the connective tissue, including SSc and rheumatoid arthritis. Elevated serum TRAIL levels have been found in SSc patients compared to healthy controls, in addition to being elevated in SSc patients with either $\mathrm{PAH}$ or $\mathrm{PF}$ compared to those without pulmonary involvement (52), suggesting that TRAIL may also may play a key role. In contrast, soluble TRAIL has been found at lower levels in the serum of patients with the idiopathic form of PF than health controls (53). Within the idiopathic $\mathrm{PF}$ patient group, lung function-shown by transfer factor of the lung for carbon monoxide-was correlated with serum levels of TRAIL, suggesting it may have a protective role in idiopathic PF (53). Furthermore, a direct link to PF pathobiology is illustrated in TRAIL-deficient mice, where fibrosis in the bleomycin model of PF was enhanced in comparison to wildtype mice (53). In this model, TRAIL deletion also increased pulmonary inflammation (neutrophil counts in bronchoalveolar lavage fluid). The inflammatory phenotype in TRAIL knockout 
mice was accompanied by a reduced number of apoptotic cells in lung tissue, with a corresponding reduction of apoptotic neutrophils in bronchoalveolar lavage fluid. This suggests that TRAIL-mediated apoptosis of neutrophils is a protective process in this form of PF.

\section{AIRWAY INFLAMMATION}

Contrary to its protective effect in idiopathic PF, TRAIL appears to have a detrimental role in the context of both acute and chronic airway inflammation, by upregulating inflammation and autoimmune responses (Figure 2). TRAIL is elevated in bronchoalveolar lavage fluid from asthmatic patients following antigen challenge, and isolated eosinophils express more TRAIL and DcR2, but less DR4 and DR5 (54). Deletion of the TRAIL gene in mice diminishes airway hyper-reactivity, inflammation and remodelling in an ovalbumin-induced model of allergic asthma $(55,56)$ and a rhinovirus-induced asthma model $(57)$. Additionally, chronic asthmatic inflammation, remodelling and lung function are worsened by TRAIL deletion in mice infected as neonates with chlamydia (58).

Prolonged exposure to irritants and inflammation can lead to chronic obstructive pulmonary disease (COPD). A role for TRAIL in COPD has been highlighted by its elevated levels in the lungs of COPD patients. One study found increased TRAIL, DR4, DR5, and DcR1 protein in lung parenchyma from COPD patients (59). Higher levels of TRAIL, DR4, and DR5 mRNA were also found in airway epithelial brushing of COPD patients compared to healthy controls (60). Another study found increased levels of serum TRAIL and DR5 in COPD patients compared to healthy controls (61). Additionally, with the COPD patient group serum levels of TRAIL and DR5 were found to be inversely correlated with forced expiratory volume (61). Inflammation and alveolar cell apoptosis are key processes in many forms of COPD. A pro-apoptotic function of TRAIL in COPD was originally suggested, as emphysematous lung tissue is more sensitive to TRAIL-induced apoptosis than health lung (62). However, a pro-inflammatory element may also be important. In a chronic cigarette smoke-exposure mouse model of COPD, TRAIL mRNA, and protein expression was increased in the airway epithelium and parenchyma, and in mice with TRAIL deletion, airway inflammation - as well as remodellingwas reduced (60). The activation by TRAIL of both apoptotic and inflammatory pathways within COPD highlights its varied roles and how specific cell types are targeted-whether or not this is this mediated by differential receptor expression or some other mechanism remains unclear.

\section{RESPIRATORY INFECTION}

In lower respiratory tract infections, TRAIL has differing roles in immune response and damage to host tissues (Figure 2). Apoptosis of virus-infected cells is a key mechanism for clearance of viral infection and in vitro. In the context of influenza infection, TRAIL-induced apoptosis of human lung alveolar epithelial cells is enhanced; an effect which is inhibited by blocking DR5 (63). Similarly, TRAIL, DR4, and DR5 are strongly upregulated in response to respiratory syncytial virus infection in pulmonary epithelial cells, leading to increased sensitivity to apoptosis (64). In animal models, TRAIL expressed by CD8+ Tcells has been demonstrated as essential for viral immunity, with TRAIL knockout mice exhibiting increased influenza-associated morbidity and reduced CD8+ T-cell cytotoxicity (65-67). DR5 expression was also shown to be upregulated in influenzainfected pulmonary epithelial cells in vivo $(63,65)$.

In opposition to its protective role in viral clearance, other studies have shown that TRAIL expressed by macrophages is instrumental in damage to airways caused by apoptosis of alveolar epithelial cells in influenza infection $(68,69)$. Deletion of TRAIL in mice led to a reduction in mortality and the alveolar epithelial apoptosis and alveolar leakage associated with influenza virus pneumonia (68). This highlights an interesting situation whereby TRAIL death signalling may be used for host for viral clearance, while also assisting in viral infection via tissue damage. TRAIL has also been demonstrated as important in immune response to bacterial respiratory infection. In the context of Streptococcus pneumoniae infection, deletion of TRAIL in mice reduces bacterial clearance in the lungs and worsens survival-an effect that is reversed by treatment with TRAIL or DR5 agonist antibody (70). In the same study, neutrophils were found to be the key source of TRAIL (70).

\section{CONCLUSIONS}

As highlighted in this mini-review, TRAIL is multifaceted in a variety of lung diseases. TRAIL also has the ability to function as either pro-apoptotic or pro-survival depending on the cells type, and receptor expression on local tissue to mediate either protective or pathogenic mechanisms. The exact mechanism by which TRAIL modulates these functions is not fully understood, although regulation of TRAIL, and its cleavage, as well as the expression of receptors by specific cell types is clearly important in determining its effects. Further work is required to fully elucidate the divergent roles of TRAIL to gain a better understanding of the role it plays in underlying processes of lung disease, and its potential as a therapeutic agent-or targetdepending on disease context.

\section{AUTHOR CONTRIBUTIONS}

$\mathrm{AB}$ was involved in conception and design of the work, drafting the article and final approval of the version to be published. HM and $\mathrm{AL}$ were involved in critical revision of the article and final approval of the version to be published.

\section{FUNDING}

AL is supported by British Heart Foundation Senior Basic Science Research Fellowship (FS/13/48/30453). AB is supported by Donald Heath Doctoral Training Fellowship. 


\section{REFERENCES}

1. Ashkenazi A, Pai RC, Fong S, Leung S, Lawrence DA, Marsters SA, et al. Safety and antitumor activity of recombinant soluble Apo2 ligand. J Clin Invest. (1999) 2:155-62. doi: 10.1172/JCI6926

2. Walczak H, Miller RE, Ariail K, Gliniak B, Griffith TS, Kubin M, et al. Tumoricidal activity of tumor necrosis factor-related apoptosis-inducing ligand in vivo. Nat Med. (1999) 2:157-63. doi: 10.1038/5517

3. Chinnaiyan AM, Prasad U, Shankar S, Hamstra DA, Shanaiah M, Chenevert TL, et al. Combined effect of tumor necrosis factor-related apoptosis-inducing ligand and ionizing radiation in breast cancer therapy. Proc Natl Acad Sci USA. (2000) 4:1754-9. doi: 10.1073/pnas.030545097

4. Cretney E, Takeda K, Yagita H, Glaccum M, Peschon JJ, Smyth MJ. Increased susceptibility to tumor initiation and metastasis in TNF-related apoptosis-inducing ligand-deficient mice. J Immunol. (2002) 3:1356-61. doi: 10.4049/jimmunol.168.3.1356

5. Johnstone RW, Frew AJ, Smyth MJ. The TRAIL apoptotic pathway in cancer onset, progression and therapy. Nat Rev Cancer (2008) 10:782-98. doi: $10.1038 /$ nrc 2465

6. Berg D, Stuhmer T, Siegmund D, Muller N, Giner T, Dittrich-Breiholz $\mathrm{O}$, et al. Oligomerized tumor necrosis factor-related apoptosis inducing ligand strongly induces cell death in myeloma cells, but also activates proinflammatory signaling pathways. FEBS J. (2009) 23:6912-27. doi: 10.1111/j.1742-4658.2009.07388.x

7. Nguyen V, Cudrici C, Zernetkina V, Niculescu F, Rus H, Drachenberg C, et al. TRAIL, DR4 and DR5 are upregulated in kidneys from patients with lupus nephritis and exert proliferative and proinflammatory effects. Clin Immunol. (2009) 1:32-42. doi: 10.1016/j.clim.2009.02.011

8. Ehrhardt H, Fulda S, Schmid I, Hiscott J, Debatin KM, Jeremias I. TRAIL induced survival and proliferation in cancer cells resistant towards TRAILinduced apoptosis mediated by NF-kappa B. Oncogene (2003) 25:3842-52. doi: 10.1038/sj.onc. 1206520

9. Baader E, Toloczko A, Fuchs U, Schmid I, Beltinger C, Ehrhardt $\mathrm{H}$, et al. Tumor necrosis factor-related apoptosis-inducing ligandmediated proliferation of tumor cells with receptor-proximal apoptosis defects. Cancer Res. (2005) 17:7888-95. doi: 10.1158/0008-5472.CAN04-4278

10. Azijli K, Yuvaraj S, Peppelenbosch MP, Wurdinger T, Dekker H, Joore J, et al. Kinome profiling of non-canonical TRAIL signaling reveals RIP1-Src-STAT3dependent invasion in resistant non-small cell lung cancer cells. J Cell Sci. (2012) (Pt 19):4651-61. doi: 10.1242/jcs.109587

11. Trauzold A, Siegmund D, Schniewind B, Sipos B, Egberts J, Zorenkov D, et al. TRAIL promotes metastasis of human pancreatic ductal adenocarcinoma. Oncogene (2006) 56:7434-39. doi: 10.1038/sj.onc.1209719

12. Gochuico BR, Zhang J, Ma BY, Marshak-Rothstein A, Fine A. TRAIL expression in vascular smooth muscle. Am J Physiol Lung Cell Mol Physiol. (2000) 5:L1045-50. doi: 10.1152/ajplung.2000.278.5.L1045

13. Lawrie A, Waterman E, Southwood M, Evans D, Suntharalingam J, Francis $\mathrm{S}$, et al. Evidence of a role for osteoprotegerin in the pathogenesis of pulmonary arterial hypertension. Am J Pathol. (2008) 1:256-64. doi: 10.2353/ajpath.2008.070395

14. Wiley SR, Schooley K, Smolak PJ, Din WS, Huang CP, Nicholl $\mathrm{JK}$, et al. Identification and characterization of a new member of the TNF family that induces apoptosis. Immunity (1995) 6:673-82. doi: 10.1016/1074-7613(95)90057-8

15. Degli-Esposti MA, Smolak PJ, Walczak H, Waugh J, Huang CP, DuBose $\mathrm{RF}$, et al. Cloning and characterization of TRAIL-R3, a novel member of the emerging TRAIL receptor family. J Exp Med. (1997) 7:1165-70. doi: 10.1084/jem.186.7.1165

16. MacFarlane M, Ahmad M, Srinivasula SM, Fernandes-Alnemri T, Cohen GM, Alnemri ES. Identification and molecular cloning of two novel receptors for the cytotoxic ligand TRAIL. J Biol Chem. (1997) 41:25417-20. doi: $10.1074 /$ jbc.272.41.25417

17. Marsters SA, Sheridan JP, Pitti RM, Huang A, Skubatch M, Baldwin D, et al. A novel receptor for Apo2L/TRAIL contains a truncated death domain. Curr Biol. (1997) 12:1003-6. doi: 10.1016/S0960-9822(06)00 $422-2$
18. Pan G, Ni J, Wei YF, Yu G, Gentz R, Dixit VM. An antagonist decoy receptor and a death domain-containing receptor for TRAIL. Science (1997) 5327:815-8.

19. Pan G, O'Rourke K, Chinnaiyan AM, Gentz R, Ebner R, Ni J, et al. The receptor for the cytotoxic ligand TRAIL. Science (1997) 5309:111-3.

20. Screaton GR, Mongkolsapaya J, Xu XN, Cowper AE, McMichael AJ, Bell JI. TRICK2, a new alternatively spliced receptor that transduces the cytotoxic signal from TRAIL. Curr Biol. (1997) 9:693-6.

21. Emery JG, McDonnell P, Burke MB, Deen KC, Lyn S, Silverman C, et al. Osteoprotegerin is a receptor for the cytotoxic ligand TRAIL. J Biol Chem. (1998) 23:14363-7. doi: 10.1074/jbc.273.23.14363

22. Schneider P, Olson D, Tardivel A, Browning B, Lugovskoy A, Gong D, et al. Identification of a new murine tumor necrosis factor receptor locus that contains two novel murine receptors for tumor necrosis factorrelated apoptosis-inducing ligand (TRAIL). J Biol Chem. (2003) 7:5444-54. doi: $10.1074 /$ jbc.M210783200

23. Hymowitz SG, Christinger HW, Fuh G, Ultsch M, O'Connell M, Kelley RF, et al. Triggering cell death: the crystal structure of Apo2L/TRAIL in a complex with death receptor 5. Mol Cell. (1999) 4:563-71. doi: 10.1016/S1097-2765(00)80207-5

24. Pitti RM, Marsters SA, Ruppert S, Donahue CJ, Moore A, Ashkenazi A. Induction of apoptosis by Apo-2 ligand, a new member of the tumor necrosis factor cytokine family. J Biol Chem. (1996) 22:12687-90. doi: $10.1074 / \mathrm{jbc} .271 .22 .12687$

25. Suliman A, Lam A, Datta R, Srivastava RK. Intracellular mechanisms of TRAIL: apoptosis through mitochondrial-dependent and -independent pathways. Oncogene (2001) 17:2122-33. doi: 10.1038/sj.onc.120 4282

26. Dickens LS, Boyd RS, Jukes-Jones R, Hughes MA, Robinson GL, Fairall L, et al. A death effector domain chain DISC model reveals a crucial role for caspase- 8 chain assembly in mediating apoptotic cell death. Mol Cell. (2012) 2:291-305. doi: 10.1016/j.molcel.2012.05.004

27. Pan G, Ni J, Yu G, Wei YF, Dixit VM. TRUNDD, a new member of the TRAIL receptor family that antagonizes TRAIL signalling. FEBS Lett. (1998) 1-2:41-45. doi: 10.1016/S0014-5793(98)00135-5

28. Miyashita T, Kawakami A, Nakashima T, Yamasaki S, Tamai M, Tanaka F, et al. Osteoprotegerin (OPG) acts as an endogenous decoy receptor in tumour necrosis factor-related apoptosis-inducing ligand (TRAIL)-mediated apoptosis of fibroblast-like synovial cells. Clin Exp Immunol. (2004) 2:430-6. doi: 10.1111/j.1365-2249.2004. 02534.x

29. Daniels RA, Turley H, Kimberley FC, Liu XS, Mongkolsapaya JP, Ch'En, et al. Expression of TRAIL and TRAIL receptors in normal and malignant tissues. Cell Res. (2005) 6:430-8. doi: 10.1038/sj.cr.7290311

30. Hameed AG, Arnold ND, Chamberlain J, Pickworth JA, Paiva C, Dawson S, et al. Inhibition of tumor necrosis factor-related apoptosis-inducing ligand (TRAIL) reverses experimental pulmonary hypertension. J Exp Med. (2012) 11:1919-35. doi: 10.1084/jem.20112716

31. Varfolomeev E, Maecker H, Sharp D, Lawrence D, Renz M, Vucic D, et al. Molecular determinants of kinase pathway activation by Apo2 ligand/tumor necrosis factor-related apoptosis-inducing ligand. J Biol Chem. (2005) 49:40599-608. doi: 10.1074/jbc.M509560200

32. Russo M, Mupo A, Spagnuolo C, Russo GL. Exploring death receptor pathways as selective targets in cancer therapy. Biochem Pharmacol. (2010) 5:674-82. doi: 10.1016/j.bcp.2010.03.011

33. Cantarella G, Di Benedetto G, Ribatti D, Saccani-Jotti G, Bernardini R. Involvement of caspase 8 and c-FLIPL in the proangiogenic effects of the tumour necrosis factor-related apoptosis-inducing ligand (TRAIL). FEBS J. (2014) 5:1505-13. doi: 10.1111/febs.12720

34. Dawson S, Arnold N, Pickworth J, Francis S, and Lawrie A. TRAIL deficient mice are protected from sugen/hypoxia induced pulmonary arterial hypertension. Diseases (2014) 3:260. doi: 10.3390/diseases203 0260

35. Liu H, Yang E, Lu X, Zuo C, He Y, Jia D, et al. Serum levels of tumor necrosis factor-related apoptosis-inducing ligand correlate with the severity of pulmonary hypertension. Pulm Pharmacol Ther. (2015) 33:39-46. doi: $10.1016 /$ j.pupt.2015.06.002 
36. Hoeper MM, Bogaard HJ, Condliffe R, Frantz R, Khanna D, Kurzyna $\mathrm{M}$, et al. Definitions and diagnosis of pulmonary hypertension. $J$ Am Coll Cardiol. (2013) 25 (Suppl.):D42-50. doi: 10.1016/j.jacc.2013. 10.032

37. Pietra GG, Edwards WD, Kay JM, Rich S, Kernis J, Schloo B, et al. Histopathology of primary pulmonary hypertension. A qualitative and quantitative study of pulmonary blood vessels from 58 patients in the National Heart, Lung, and Blood Institute, Primary Pulmonary Hypertension Registry. Circulation (1989) 5:1198-206. doi: 10.1161/01.CIR.80.5. 1198

38. Lawrie A, Hameed AG, Chamberlain J, Arnold N, Kennerley A, Hopkinson $\mathrm{K}$, et al. Paigen diet-fed apolipoprotein E knockout mice develop severe pulmonary hypertension in an interleukin-1-dependent manner. Am J Pathol. (2011) 4:1693-705. doi: 10.1016/j.ajpath.2011.06.037

39. Secchiero P, Zerbinati C, Rimondi E, Corallini F, Milani D, Grill V, et al. TRAIL promotes the survival, migration and proliferation of vascular smooth muscle cells. Cell Mol Life Sci. (2004) 15:1965-74. doi: 10.1007/s00018-0044197-6

40. Kavurma MM, Schoppet M, Bobryshev YV, Khachigian LM, Bennett MR. TRAIL stimulates proliferation of vascular smooth muscle cells via activation of NF-kappaB and induction of insulin-like growth factor-1 receptor. J Biol Chem. (2008) 12:7754-62. doi: 10.1074/jbc.M706927200

41. Song S, Choi K, Ryu SW, Kang SW, Choi C. TRAIL promotes caspase-dependent pro-inflammatory responses via PKCdelta activation by vascular smooth muscle cells. Cell Death Dis. (2011) 2:e223. doi: 10.1038/cddis.2011.103

42. Secchiero P, Gonelli A, Carnevale E, Milani D, Pandolfi A, Zella D, et al. TRAIL promotes the survival and proliferation of primary human vascular endothelial cells by activating the Akt and ERK pathways. Circulation (2003) 17:2250-56. doi: 10.1161/01.CIR.0000062702.607 08.C4

43. Cartland SP, Genner SW, Zahoor A, Kavurma MM. Comparative evaluation of TRAIL, FGF-2 and VEGF-a-induced angiogenesis in vitro and in vivo. Int $J$ Mol Sci. (2016) 12:E2025. doi: 10.3390/ijms17122025

44. Zauli G, Pandolfi A, Gonelli A, Di Pietro R, Guarnieri S, Ciabattoni G, et al. Tumor necrosis factor-related apoptosis-inducing ligand (TRAIL) sequentially upregulates nitric oxide and prostanoid production in primary human endothelial cells. Circ Res. (2003) 7:732-40. doi: 10.1161/01.RES.0000067928.83455.9C

45. Harith HH, Di Bartolo BA, Cartland SP, Genner S, Kavurma MM. Insulin promotes vascular smooth muscle cell proliferation and apoptosis via differential regulation of tumor necrosis factor-related apoptosisinducing ligand. J Diabetes. (2016) 4:568-78. doi: 10.1111/1753-0407. 12339

46. Alladina SJ, Song JH, Davidge ST, Hao C, Easton AS. TRAIL-induced apoptosis in human vascular endothelium is regulated by phosphatidylinositol 3-kinase/Akt through the short form of cellular FLIP and Bcl-2. J Vasc Res. (2005) 4:337-47. doi: 10.1159/000086599

47. Cantarella G, Risuglia NR, Dell'eva, Lempereur L, Albini A, Pennisi G, et al. TRAIL inhibits angiogenesis stimulated by VEGF expression in human glioblastoma cells. Br J Cancer (2006) 10:1428-35. doi: 10.1038/sj.bjc.660 3092

48. Finnberg N, Klein-Szanto AJ, El-Deiry W S. TRAIL-R deficiency in mice promotes susceptibility to chronic inflammation and tumorigenesis. J Clin Invest. (2008) 1:111-23. doi: 10.1172/JCI29900

49. McGrath EE, Marriott HM, Lawrie A, Francis SE, Sabroe I, Renshaw SA, et al. TNF-related apoptosis-inducing ligand (TRAIL) regulates inflammatory neutrophil apoptosis and enhances resolution of inflammation. J Leukoc Biol. (2011) 5:855-65. doi: 10.1189/jlb.0211062

50. Mukerjee D, St George D, Coleiro B, Knight C, Denton CP, Davar J, et al. Prevalence and outcome in systemic sclerosis associated pulmonary arterial hypertension: application of a registry approach. Ann Rheum Dis. (2003) 11:1088-93. doi: 10.1136/ard.62.11.1088

51. Hachulla E, Gressin V, Guillevin L, Carpentier P, Diot E, Sibilia $\mathrm{J}$, et al. Early detection of pulmonary arterial hypertension in systemic sclerosis: a French nationwide prospective multicenter study. Arthritis Rheum. (2005) 12:3792-800. doi: 10.1002/art. 21433
52. Azab NA, Rady HM, Marzouk S A. Elevated serum TRAIL levels in scleroderma patients and its possible association with pulmonary involvement. Clin Rheumatol. (2012) 9:1359-64. doi: 10.1007/s10067-012-2023-3

53. McGrath EE, Lawrie A, Marriott HM, Mercer P, Cross SS, Arnold N, et al. Deficiency of tumour necrosis factor-related apoptosis-inducing ligand exacerbates lung injury and fibrosis. Thorax. (2012) 9:796-803. doi: 10.1136/thoraxjnl-2011-200863

54. Robertson NM, Zangrilli JG, Steplewski A, Hastie A, Lindemeyer RG, Planeta MA, et al. Differential expression of TRAIL and TRAIL receptors in allergic asthmatics following segmental antigen challenge: evidence for a role of TRAIL in eosinophil survival. J Immunol. (2002) 10:5986-96. doi: 10.4049/jimmunol.169.10.5986

55. Weckmann M, Collison A, Simpson JL, Kopp MV, Wark PA, Smyth MJ, et al. Critical link between TRAIL and CCL20 for the activation of TH2 cells and the expression of allergic airway disease. Nat Med. (2007) 11:1308-15. doi: $10.1038 / \mathrm{nm} 1660$

56. Collison A, Li JA, Pereira de Siqueira, Zhang J, Toop HD, Morris JC et al. Tumor necrosis factor-related apoptosis-inducing ligand regulates hallmark features of airways remodeling in allergic airways disease. Am J Respir Cell Mol Biol. (2014) 1:86-93. doi: 10.1165/rcmb.20130490OC

57. Girkin JL, Hatchwell LM, Collison AM, Starkey MR, Hansbro PM, Yagita H, et al. TRAIL signaling is proinflammatory and proviral in a murine model of rhinovirus 1B infection. Am J Physiol Lung Cell Mol Physiol. (2017) 1:L89-99. doi: 10.1152/ajplung.00200.2016

58. Starkey MR, Nguyen DH, Essilfie AT, Kim RY, Hatchwell LM, Collison $\mathrm{AM}$, et al. Tumor necrosis factor-related apoptosis-inducing ligand translates neonatal respiratory infection into chronic lung disease. Mucosal Immunol. (2014) 3:478-88. doi: 10.1038/mi.2013.65

59. Morissette MC, Vachon-Beaudoin G, Parent J, Chakir J, Milot J. Increased p53 level, Bax/Bcl-x(L) ratio, and TRAIL receptor expression in human emphysema. Am J Respir Crit Care Med. (2008) 3:240-7. doi: 10.1164/rccm.200710-1486OC

60. Haw TJ, Starkey MR, Nair PM, Pavlidis S, Liu G, Nguyen DH, et al. A pathogenic role for tumor necrosis factor-related apoptosis-inducing ligand in chronic obstructive pulmonary disease. Mucosal Immunol. (2016) 4:859-72. doi: $10.1038 / \mathrm{mi} .2015 .111$

61. Wu Y, Shen Y, Zhang J, Wan C, Wang T, Xu D, et al. Increased serum TRAIL and DR5 levels correlated with lung function and inflammation in stable COPD patients. Int J Chron Obstruct Pulmon Dis. (2015) 2015:2405-2412. doi: 10.2147/COPD.S92260

62. Morissette MC, Parent J, Milot J. The emphysematous lung is abnormally sensitive to TRAIL-mediated apoptosis. Respir Res. (2011) 12:105. doi: 10.1186/1465-9921-12-105

63. Brincks EL, Kucaba TA, Legge KL, Griffith TS. Influenza-induced expression of functional tumor necrosis factor-related apoptosisinducing ligand on human peripheral blood mononuclear cells. Hum Immunol. (2008b) 10:634-46. doi: 10.1016/j.humimm.2008. 07.012

64. Kotelkin A, Prikhod'ko EA, Cohen JI, Collins PL, Bukreyev A. Respiratory syncytial virus infection sensitizes cells to apoptosis mediated by tumor necrosis factor-related apoptosis-inducing ligand. J Virol. (2003) 17:9156-72. doi: 10.1128/JVI.77.17.9156-9172. 2003

65. Ishikawa E, Nakazawa M, Yoshinari M, Minami M. Role of tumor necrosis factor-related apoptosis-inducing ligand in immune response to influenza virus infection in mice. J Virol. (2005) 12:7658-63. doi: 10.1128/JVI.79.12.7658-7663.2005

66. Brincks EL, Katewa A, Kucaba TA, Griffith TS, Legge KL. CD8 T cells utilize TRAIL to control influenza virus infection. J Immunol. (2008) 7:4918-25. doi: 10.4049/jimmunol.181.7.4918

67. Brincks EL, Gurung P, Langlois RA, Hemann EA, Legge KL, Griffith TS. The magnitude of the $\mathrm{T}$ cell response to a clinically significant dose of influenza virus is regulated by TRAIJL. J Immunol. (2011) 9:4581-8. doi: 10.4049/jimmunol.1002241

68. Herold S, Steinmueller M, von Wulffen W, Cakarova L, Pinto R, Pleschka $S$, et al. Lung epithelial apoptosis in influenza virus pneumonia: the role of 
macrophage-expressed TNF-related apoptosis-inducing ligand. J Exp Med. (2008) 13:3065-77. doi: 10.1084/jem.20080201

69. Peteranderl C, Morales-Nebreda L, Selvakumar B, Lecuona E, Vadasz I, Morty RE, et al. Macrophage-epithelial paracrine crosstalk inhibits lung edema clearance during influenza infection. J Clin Invest. (2016) 4:1566-80. doi: 10.1172/JCI83931

70. Steinwede K, Henken S, Bohling J, Maus R, Ueberberg B, Brumshagen $\mathrm{C}$, et al. TNF-related apoptosis-inducing ligand (TRAIL) exerts therapeutic efficacy for the treatment of pneumococcal pneumonia in mice. J Exp Med. (2012) 11:1937-52. doi: 10.1084/jem.201 20983
Conflict of Interest Statement: The authors declare that the research was conducted in the absence of any commercial or financial relationships that could be construed as a potential conflict of interest.

Copyright () 2018 Braithwaite, Marriott and Lawrie. This is an open-access article distributed under the terms of the Creative Commons Attribution License (CC BY). The use, distribution or reproduction in other forums is permitted, provided the original author(s) and the copyright owner(s) are credited and that the original publication in this journal is cited, in accordance with accepted academic practice. No use, distribution or reproduction is permitted which does not comply with these terms. 